\title{
RECYCLING ROMAN GLASS TO GLAZE PARTHIAN POTTERY
}

\author{
By JONATHAN R. WOOD AND YI-TING HSU
}

\begin{abstract}
Alkaline glazes were first used on clay-based ceramics in Mesopotamia around 1500 B.C., at the same time as the appearance of glass vessels. The Roman Empire used lead-based glazes, with alkaline natron glass being used only to produce objects of glass. Chemical analysis has had some success determining compositional groups for Roman/Byzantine/early Islamic glasses because of the discovery of major production sites. Parthian and Sasanian glass and glazed wares, however, have been found only in consumption assemblages, which have failed to inform on how they were made. Here we reanalyse compositional data for Parthian and Sasanian glazes and present new analyses for Parthian glazed pottery excavated at the early third century A.D. Roman military outpost of Ain Sinu in northern Iraq. We show that some Parthian glazes are from a different tradition to typical Mesopotamian glazes and have compositions similar to Roman glass. We propose that Roman glass was recycled by Parthian potters, thereby suggesting that as yet undiscovered Mesopotamian glass production centres ordinarily supplied glass for indigenous glazed pottery. Furthermore, if recycling glass to make glazed pottery was extended to indigenous glassware, this may provide an explanation for the paucity of Parthian and Sasanian glass in the archaeological record.
\end{abstract}

Keywords: Roman frontier, Parthian and Sasanian glazes, Roman glass, Recycle, Ain Sinu

\section{Introduction}

Alkaline glazes were first used on clay-based ceramics in Mesopotamia around 1500 B.C., at the same time as the appearance of the first glass vessels, establishing a tradition of making glazes with plant ash which continued through to the early Islamic period (Freestone 1991; Hedges and Moorey 1975). By contrast, the Roman Empire used lead-based glazes (Hatcher et al. 1994; Walton and Tite 2010), with alkaline natron glass being used only to produce objects of glass (Freestone 1991). Attempts to find chemical compositional groups have had some success for the relatively chemically homogenous Roman/Byzantine/early Islamic glasses because of the discovery of major production sites (Freestone 2013; Freestone and Gorin-Rosen 1999) and for medieval European glass-making, where raw materials were obtained locally to produce vessels of distinctive compositions (Freestone 2005). Parthian and Sasanian glass and glazed wares, however, have only been found in consumption rather than production assemblages which, in addition to the low amounts recovered, have so far failed to yield meaningful compositional groups from which to develop proposals on where and how they were made (Brill 2005).

Ain Sinu in northern Iraq, also known as Zagurae, was contested territory for both the Parthian (247 B.C.-A.D. 224) and Sasanian (A.D. 224-651) empires, being occupied by the Romans between A.D. 197-364 (Oates and Oates 1959) (Figs. 1 and 2). As a frontier outpost on the main route between Singara and the Tigris, little Romanisation occurred apart from that required by the military. This lack of western influence extended to its material culture, with very few western imports being found (Oates and Oates 1959; Oates 1968). Glazed pottery, however, is common at Ain Sinu (Fig. 3), in contrast to the ornate but unglazed wares generally recovered in northern Mesopotamia (Oates 1968). This suggests that this remote outpost may have had its own glaze tradition, influenced by the presence of the Roman military. Against this background we present an approach to examine chemical compositional signatures of Mesopotamian glazed wares (Fig. 3) from which to investigate a sample of glazed sherds recovered at Ain Sinu by Professor David Oates and Dr. Joan Oates.

\section{Re-analyses of Parthian and Sasanian glaze legacy data}

The approach applied was first to examine legacy data from chemical studies of glazed pottery from the Parthian and Sasanian periods, in order to identify compositional signatures (i.e., meaningful 


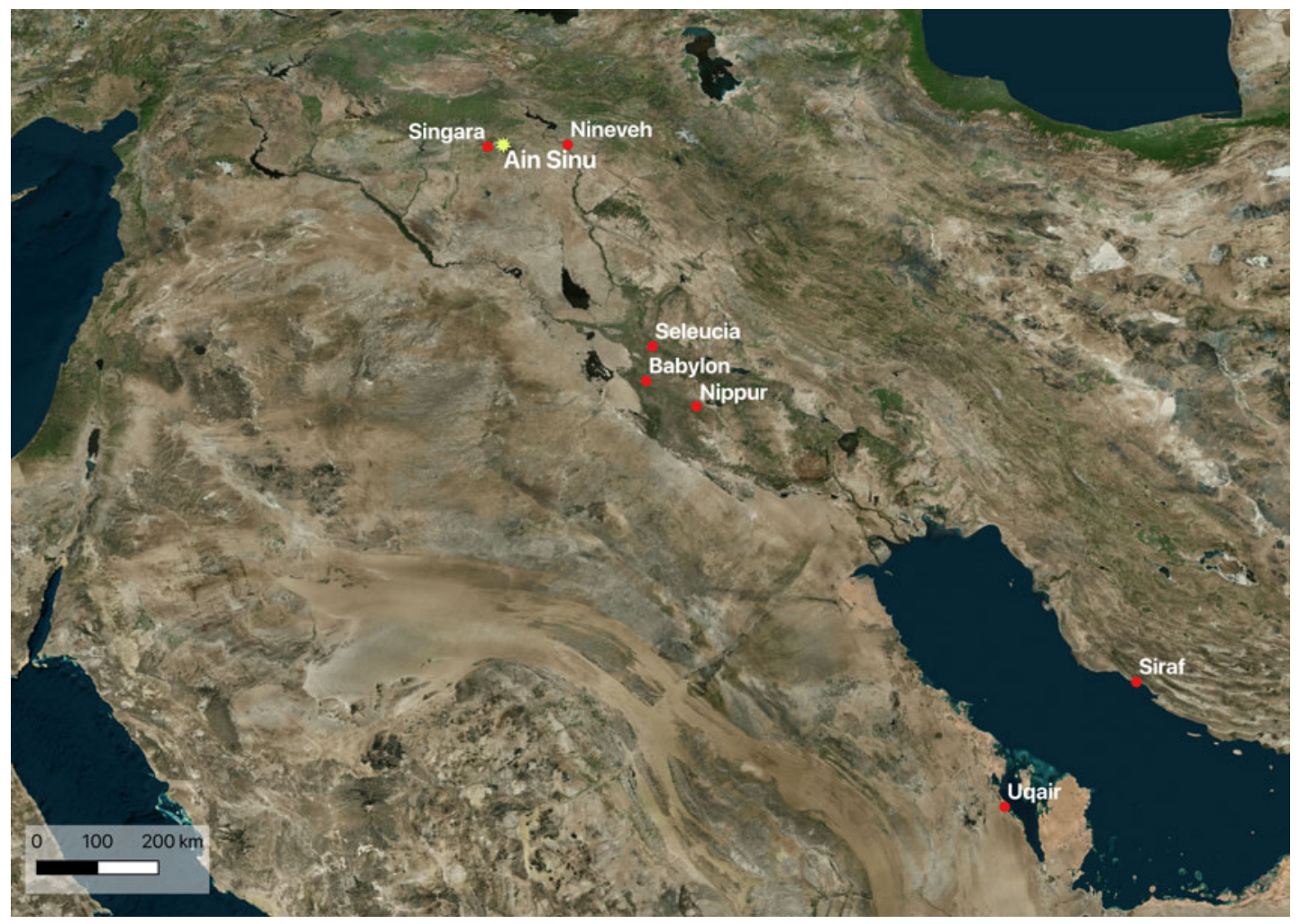

Fig. 1 Map showing the location of Ain Sinu and other sites mentioned in the text

patterns in the data which could inform on production practice that may have, so far, been overlooked), and to present new compositional data from glazed sherds recovered at Ain Sinu.

The following criteria were used to select glazes in the archaeological record to determine representative Parthian and Sasanian compositional signatures:

- Samples classified as Parthian, Sasanian or Parthian-Sasanian were included in the analyses. Those classified as Sasanian/Early Islamic, or similar, were not included.

- Gravimetric methods, e.g., Matson (1943), or semi-quantitative techniques which could not measure the full suite of major element oxides, e.g. portable X-ray fluorescence (pXRF) were excluded. The glaze compositions reanalysed were generated from two analytical techniques: energy dispersive spectroscopy (EDS) or wavelength dispersive spectroscopy (WDS).

- Glazes of all colours were included on the assumption that additives that modified the glaze colour were added to the same base glaze and reflected variations in oxidising conditions in the kiln, rather than variations in the base compositional 'recipes' of the glazes.

The main components of Mesopotamian glazes derive from silica and plant ash (Brill 2005; Freestone 2013; Hedges and Morrey 1975; Simpson 1997a) and contain oxides of silicon, aluminium, iron, magnesium, calcium, potassium and sodium $\left(\mathrm{SiO}_{2}, \mathrm{Al}_{2} \mathrm{O}_{3}, \mathrm{FeO}, \mathrm{MgO}, \mathrm{CaO}\right.$, $\mathrm{K}_{2} \mathrm{O}$ and $\mathrm{Na}_{2} \mathrm{O}$, respectively). Levels of these major element oxides for 53 Parthian and Sasanian glazed wares (Table 1) were found to overlap between sites, thereby limiting the application of compositional averages or bivariate plots to determine discriminators regarding the grouping of sites, glaze production practices or chronologies.

Essentially, one of the main problems in comparing percentages of each chemical component which make up a glaze (or any multicomponent system) is that compositions are fundamentally multivariate in nature. That is, even if one part of a composition is reported, it is implicitly related to the other components. By this rationale, an individual variable, such as the percentage of silica 


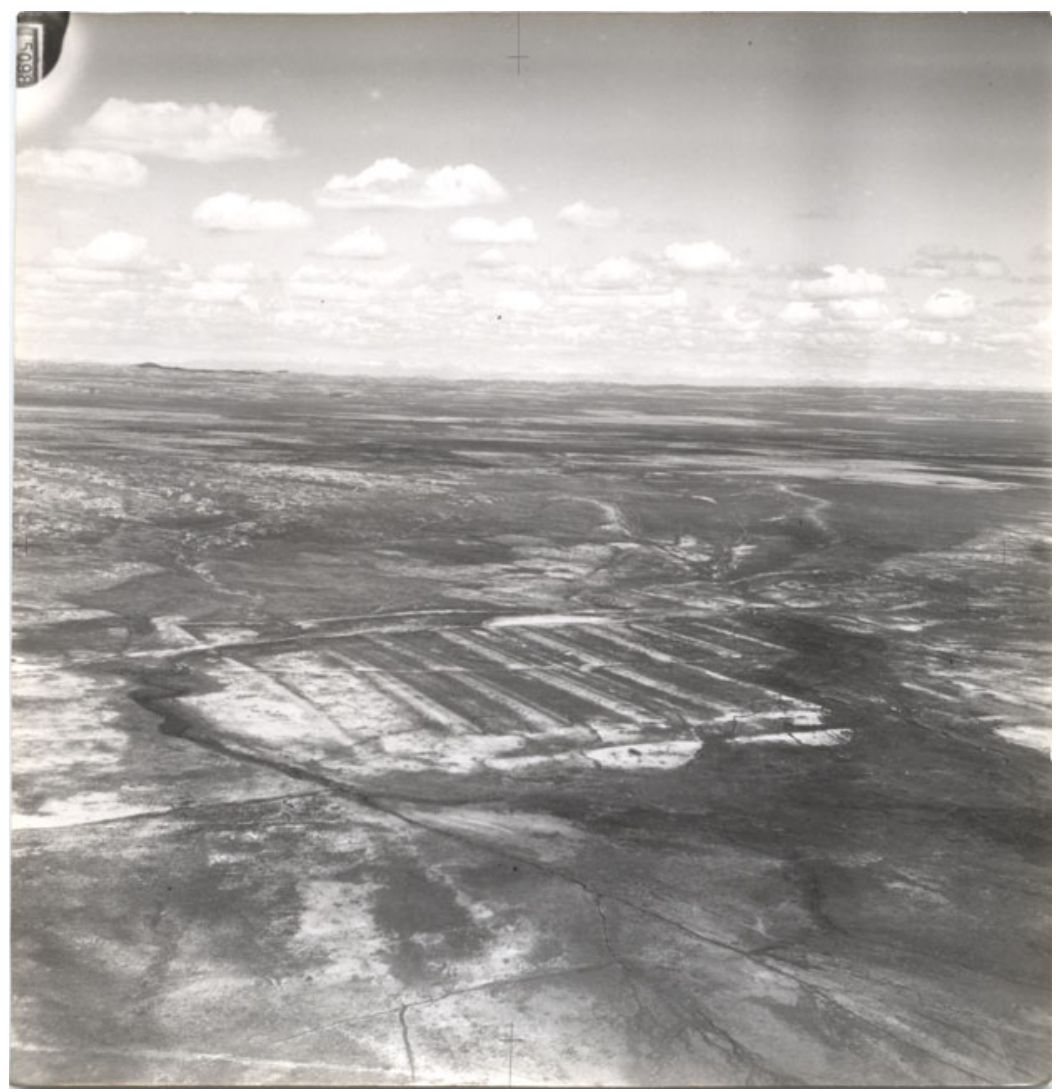

Fig. 2 Aerial photograph of Ain Sinu from the British Academy, Sir M. Aurel Stein Collection (item: ASA/3/ 35; Obverse: 15098). Use of photograph permitted by British Academy.
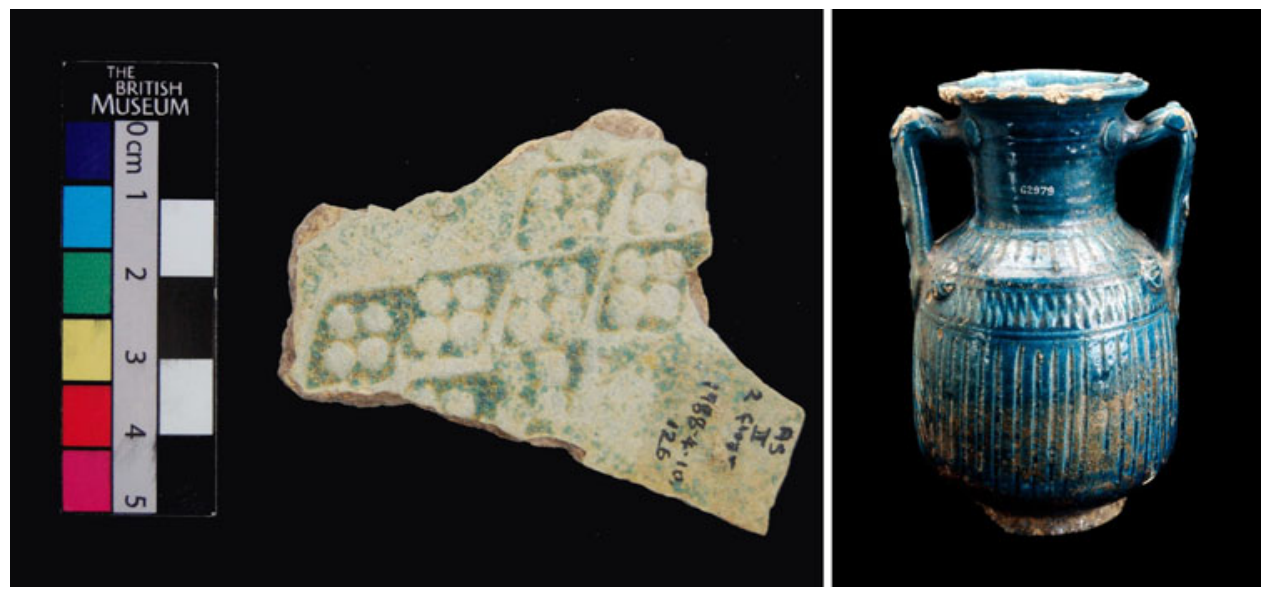

Fig. 3 Left: Glazed sherd from Ain Sinu held at the British Museum (item: 1988, 0410.126) showing the diagnostic Parthian diamond-stamp pattern. Right: Parthian blue-glazed pottery jar (second-third century A.D.) recovered in North Syria (item: 1915, 1218.1). Use of photographs permitted by British Museum.

in a glaze, has no meaning unless it is related to the whole compositional data set. On first inspection, this would appear to be resolved by normalising raw data to $100 \%$. However, it must be noted that this mathematical operation does not circumvent the fact that the whole data set is rarely (if ever) 
TABLE 1 Sites, data sources and techniques and chronologies of the legacy data. All concentrations are in normalised compound percent ( $\mathrm{wt} \%$ oxide). Note that additional oxides were measured in some studies.

\begin{tabular}{|c|c|c|c|c|c|c|c|c|c|c|}
\hline Site & Source & Technique & Chronology & $\mathrm{SiO}_{2}$ & $\mathrm{Al}_{2} \mathrm{O}_{3}$ & $\mathrm{FeO}$ & $M g O$ & $\mathrm{CaO}$ & $\mathrm{K}_{2} \mathrm{O}$ & $\mathrm{Na}_{2} \mathrm{O}$ \\
\hline Deh Luran & Hill (2006) & EDS & Sasanian & 67.21 & 4.44 & 0.85 & 2.12 & 6.28 & 4.46 & 8.68 \\
\hline \multirow[t]{2}{*}{ Plain, Iran } & & & Sasanian & 70.75 & 2.97 & 0.76 & 1.95 & 4.2 & 2.9 & 11.39 \\
\hline & & & Parthian & 62.54 & 2.57 & 3.71 & 3.20 & 7.78 & 4.82 & 8.17 \\
\hline \multirow[t]{19}{*}{ Nippur, Iraq } & \multirow{15}{*}{$\begin{array}{l}\text { McCarthy } \\
\text { (1996) }\end{array}$} & \multirow[t]{15}{*}{ WDS } & Parthian & 66.07 & 3.66 & 1.43 & 4.09 & 7.27 & 4.64 & 10.27 \\
\hline & & & Parthian & 62.99 & 5.95 & 1.16 & 3.67 & 6.32 & 5.61 & 13.37 \\
\hline & & & Parthian & 62.19 & 6.01 & 2.70 & 6.34 & 11.16 & 3.87 & 5.90 \\
\hline & & & Parthian & 61.78 & 5.88 & 2.72 & 3.38 & 5.40 & 4.94 & 12.87 \\
\hline & & & Parthian & 69.92 & 7.26 & 1.08 & 2.51 & 5.17 & 5.74 & 6.41 \\
\hline & & & Parthian & 65.18 & 4.94 & 1.68 & 3.00 & 7.30 & 5.44 & 9.88 \\
\hline & & & Parthian & 66.54 & 2.19 & 5.00 & 3.47 & 6.32 & 5.12 & 11.28 \\
\hline & & & Parthian & 58.46 & 12.93 & 3.31 & 3.31 & 6.87 & 5.56 & 8.55 \\
\hline & & & Parthian & 60.30 & 3.15 & 3.98 & 3.04 & 6.33 & 4.74 & 13.93 \\
\hline & & & Parthian & 63.00 & 4.08 & 2.79 & 5.27 & 9.25 & 3.57 & 10.15 \\
\hline & & & Parthian & 59.84 & 2.19 & 4.84 & 4.15 & 7.33 & 6.54 & 10.75 \\
\hline & & & Parthian-Sasanian & 62.11 & 3.28 & 0.96 & 4.12 & 7.29 & 4.36 & 16.3 \\
\hline & & & Parthian-Sasanian & 66.19 & 3.23 & 1.32 & 3.7 & 5.41 & 5.38 & 13.88 \\
\hline & & & Sasanian & 64.26 & 3.51 & 1.05 & 4.38 & 7.2 & 3.73 & 14.76 \\
\hline & & & Sasanian & 65.94 & 3.11 & 0.89 & 3.69 & 6.99 & 4.86 & 10.47 \\
\hline & Mason and & WDS & Parthian & 62.2 & 2.8 & 1.3 & 2.4 & 7.3 & 4.5 & 19.6 \\
\hline & Tite (1997) & & Sasanian & 67.4 & 2.6 & 3.00 & 3.3 & 8.4 & 5.7 & 9.6 \\
\hline & \multirow[t]{2}{*}{ Mason (2004) } & \multirow{2}{*}{ WDS } & Parthian & 63.4 & 4.4 & 0.8 & 3.9 & 7.1 & 4.2 & 16.2 \\
\hline & & & Parthian & 65.8 & 3.8 & 0.9 & 4.0 & 7.9 & 4.2 & 13.2 \\
\hline \multirow{7}{*}{$\begin{array}{l}\text { Excavated in } \\
\text { Aksum, } \\
\text { Ethiopia }\end{array}$} & \multirow{7}{*}{$\begin{array}{l}\text { Freestone } \\
\text { (2013) }\end{array}$} & \multirow[t]{7}{*}{ EDS } & Sasanian & 66.33 & 1.49 & 1.42 & 3.74 & 7.81 & 4.71 & 10.29 \\
\hline & & & Sasanian & 65.19 & 1.57 & 1.87 & 4.44 & 8.76 & 4.31 & 9.46 \\
\hline & & & Sasanian & 67.11 & 2.02 & 2.54 & 4.91 & 10.05 & 4.34 & 7.85 \\
\hline & & & Sasanian & 66.16 & 1.75 & 2.32 & 4.33 & 8.58 & 5.04 & 10.09 \\
\hline & & & Sasanian & 65.51 & 1.59 & 0.81 & 4.48 & 8.12 & 5.15 & 9.42 \\
\hline & & & Sasanian & 65.05 & 2.14 & 0.97 & 3.83 & 7.48 & 3.95 & 13.31 \\
\hline & & & Sasanian & 65.54 & 1.53 & 2.32 & 4.27 & 8.85 & 4.86 & 10.17 \\
\hline British & \multirow{8}{*}{$\begin{array}{l}\text { Freestone } \\
\text { (2013) }\end{array}$} & \multirow[t]{8}{*}{ EDS } & Parthian-Sasanian & 60.39 & 3.13 & 1.54 & 5.61 & 10.3 & 3.59 & 8.40 \\
\hline Museum: & & & Parthian-Sasanian & 70.4 & 1.50 & 0.78 & 2.03 & 6.11 & 6.68 & 8.98 \\
\hline Babylon, & & & Parthian-Sasanian & 63.97 & 1.56 & 0.89 & 3.33 & 7.09 & 4.70 & 10.68 \\
\hline Susa, Warka, & & & Parthian-Sasanian & 68.55 & 2.30 & 0.71 & 3.40 & 6.30 & 3.58 & 12.54 \\
\hline Sippar, & & & Parthian-Sasanian & 64.31 & 4.22 & 1.33 & 4.55 & 6.36 & 3.45 & 11.27 \\
\hline Nineveh, & & & Parthian-Sasanian & 64.03 & 3.73 & 4.16 & 2.79 & 5.96 & 5.18 & 11.44 \\
\hline \multirow[t]{2}{*}{ unknown } & & & Parthian-Sasanian & 64.44 & 4.21 & 1.99 & 4.36 & 8.28 & 4.39 & 10.03 \\
\hline & & & Parthian-Sasanian & 63.94 & 5.79 & 2.87 & 2.85 & 5.08 & 5.69 & 11.54 \\
\hline \multirow[t]{2}{*}{ Nishapur, Iran } & \multirow{2}{*}{$\begin{array}{l}\text { Collinet and } \\
\text { Rante (2013) }\end{array}$} & \multirow[t]{2}{*}{ EDS } & Sasanian & 67.07 & 2.45 & 1.14 & 3.23 & 5.96 & 5.56 & 11.03 \\
\hline & & & Sasanian & 65.75 & 4.27 & 1.98 & 3.54 & 7.94 & 4.30 & 9.83 \\
\hline Seleucia, Iraq & $\begin{array}{l}\text { Pace et al. } \\
(2008)\end{array}$ & EDS & 1-3rd Century A.D. & 69.1 & 3.6 & 1.5 & 3.1 & 7.7 & 7.8 & 6.4 \\
\hline Veh Ardasir, & \multirow{13}{*}{$\begin{array}{l}\text { Pace et al. } \\
(2008)\end{array}$} & EDS & Sasanian & 60.2 & 4.4 & 1.7 & 4.5 & 9.3 & 4.1 & 12.8 \\
\hline \multirow[t]{12}{*}{ Iraq } & & & Sasanian & 60.5 & 4.2 & 1.3 & 4.9 & 9.8 & 4.7 & 13.4 \\
\hline & & & Sasanian & 64.7 & 2.2 & 1.5 & 3.9 & 7.6 & 4 & 10.9 \\
\hline & & & Sasanian & 63.5 & 3 & 1.4 & 4.7 & 7.7 & 4.5 & 12.8 \\
\hline & & & Sasanian & 60.4 & 4 & 1.9 & 5.2 & 10 & 4.5 & 11.3 \\
\hline & & & Sasanian & 63.9 & 2.3 & 1.1 & 4.3 & 7.8 & 4.6 & 12.9 \\
\hline & & & Sasanian & 68.4 & 2.6 & 1.5 & 5 & 8.4 & 4.9 & 8.2 \\
\hline & & & Sasanian & 68.3 & 1.9 & 1 & 3.6 & 7.1 & 3.9 & 9.4 \\
\hline & & & Sasanian & 67.6 & 2.1 & 1.3 & 4.4 & 8 & 3.5 & 9.2 \\
\hline & & & Sasanian & 67 & 3 & 1.4 & 3.9 & 8.5 & 3.7 & 8.6 \\
\hline & & & Sasanian & 67.6 & 1.5 & 0.9 & 3.8 & 6.9 & 4.1 & 10.8 \\
\hline & & & Sasanian & 65.9 & 3.1 & 1.3 & 3.3 & 8.1 & 4.9 & 10.1 \\
\hline & & & Sasanian & 67.2 & 3.6 & 1.9 & 4 & 7.8 & 3.6 & 8.8 \\
\hline
\end{tabular}


TABLE 2 Variation matrix showing the co-dependence of the major oxides in the legacy data.

\begin{tabular}{llllllll}
\hline & $\mathrm{SiO}_{2}$ & $\mathrm{Al}_{2} \mathrm{O}_{3}$ & $\mathrm{FeO}$ & $\mathrm{MgO}$ & $\mathrm{CaO}$ & $\mathrm{K}_{2} \mathrm{O}$ & $\mathrm{Na}_{2} \mathrm{O}$ \\
\hline $\mathrm{SiO}_{2}$ & 0 & 0.228 & 0.290 & 0.071 & 0.044 & 0.036 & 0.064 \\
$\mathrm{Al}_{2} \mathrm{O}_{3}$ & 0.228 & 0 & 0.386 & 0.283 & 0.275 & 0.233 & 0.273 \\
$\mathrm{FeO}$ & 0.290 & 0.386 & 0 & 0.287 & 0.269 & 0.251 & 0.370 \\
$\mathrm{MgO}$ & 0.071 & 0.283 & 0.287 & 0 & 0.026 & 0.124 & 0.123 \\
$\mathrm{CaO}$ & 0.044 & 0.275 & 0.269 & 0.026 & 0 & 0.084 & 0.114 \\
$\mathrm{~K}_{2} \mathrm{O}$ & 0.036 & 0.233 & 0.251 & 0.124 & 0.084 & 0 & 0.103 \\
$\mathrm{Na}_{2} \mathrm{O}$ & 0.064 & 0.273 & 0.370 & 0.123 & 0.114 & 0.103 & 0 \\
\hline
\end{tabular}

measured. For example, portable x-ray fluorescence spectrometry (pXRF) cannot generally detect many of the lighter elements found in glass, glazes and pottery. In other words, the amounts that are measured do not add up to the real total. This makes comparisons difficult, as different data sets will have been measured in different ways, often focussing on different parts of the composition.

In effect, most compositional approaches treat compositional data as if they were just multivariate real datasets that incidentally happen to be positive and sum to 1 (or 100\%). This is because these methods focus on representing transfer of 'mass' between parts. However, the total mass in each observation is not so relevant (i.e. it is not necessarily useful to know there is $5 \mathrm{~g}$ of $\mathrm{SiO}_{2}$ in the sample). It is more appropriate to consider that all compositional data are actually subcompositional (Aitchison 1986, 2005), e.g., silica is part of a sub-composition of the glaze components measured. An example of this problem comes from Hedges and Moorey's paper (1975), where the percentages of silica present in the Sasanian glazes were not measured directly but calculated by subtracting the sum of the other components from $100 \%$. Although this provides a useful approximation of the amount of silica expected in these glazes, it is clearly difficult to compare accurately with other studies which have measured additional (or fewer) components.

The re-analysis conducted here treats the system as a series of sub-compositional components, by transforming the data to a log-ratio scale (Aitchison 1986, 2005; Wood and Hsu 2019). This method was first proposed by Aitchison (1986) who defined a relative geometry where only the ratios of the different components were considered. A few years later it was realised that the mathematical structure Aitchison had defined was a vector space structure in its own right, which allowed compositions consisting of $\mathrm{D}$ parts to be converted to a classic multivariate problem involving real vectors of (D-1) co-ordinates, i.e., the principle of working in coordinates (Pawlowsky-Glahn 2004). Although ratios have been applied to compositional data to distinguish between different types of natron glass (e.g., Phelps et al. 2016), a log-ratio approach is robust as it removes the effects of the constant sum constraint (which compels the data to lay between 0 and $100 \%$ ) in order to eliminate any 'spurious correlations' (Chayes 1949). In essence, the log-ratio approach considers from the outset that the interest lies in the relative magnitudes and variations of components, instead of in their absolute values, and that the data is unconstrained (thereby retaining the proper covariance structure of any compositional data) before using the full range of standard methods available for statistical inference to identify groups or patterns.

Multivariate analyses were performed using the 'Compositions' package in R created by van den Boogaart (2013), applying Aitchison's geometry (i.e., centred log-ratio transformation) to the raw compositional data (Aitchison 1986, 2005). We believe that this is a more consistent way of dealing with compositional data, especially when it is highly unlikely that the amounts of all components are known.

The spread of the compositional data was determined from the variation in the log-ratios (Aitchison 1986). The variation matrix (Table 2) identifies co-dependence between $\mathrm{SiO}_{2}$ and $\mathrm{MgO}$ (0.071), $\mathrm{CaO}(0.044), \mathrm{K}_{2} \mathrm{O}(0.036)$ and $\mathrm{Na}_{2} \mathrm{O}(0.064)$ and between $\mathrm{MgO}$ and $\mathrm{CaO}(0.026)$, and $\mathrm{K}_{2} \mathrm{O}$ and $\mathrm{CaO}(0.084)$, i.e., low values in the variation matrix. As these components are generally prerequisite to produce stable glasses and glazes, these co-dependencies were expected; that is, there are physico-chemical limits to how much these components can vary in order to successfully make a glaze. However, there is relatively low co-dependence between $\mathrm{K}_{2} \mathrm{O}$ and $\mathrm{MgO}(0.124)$ - an 

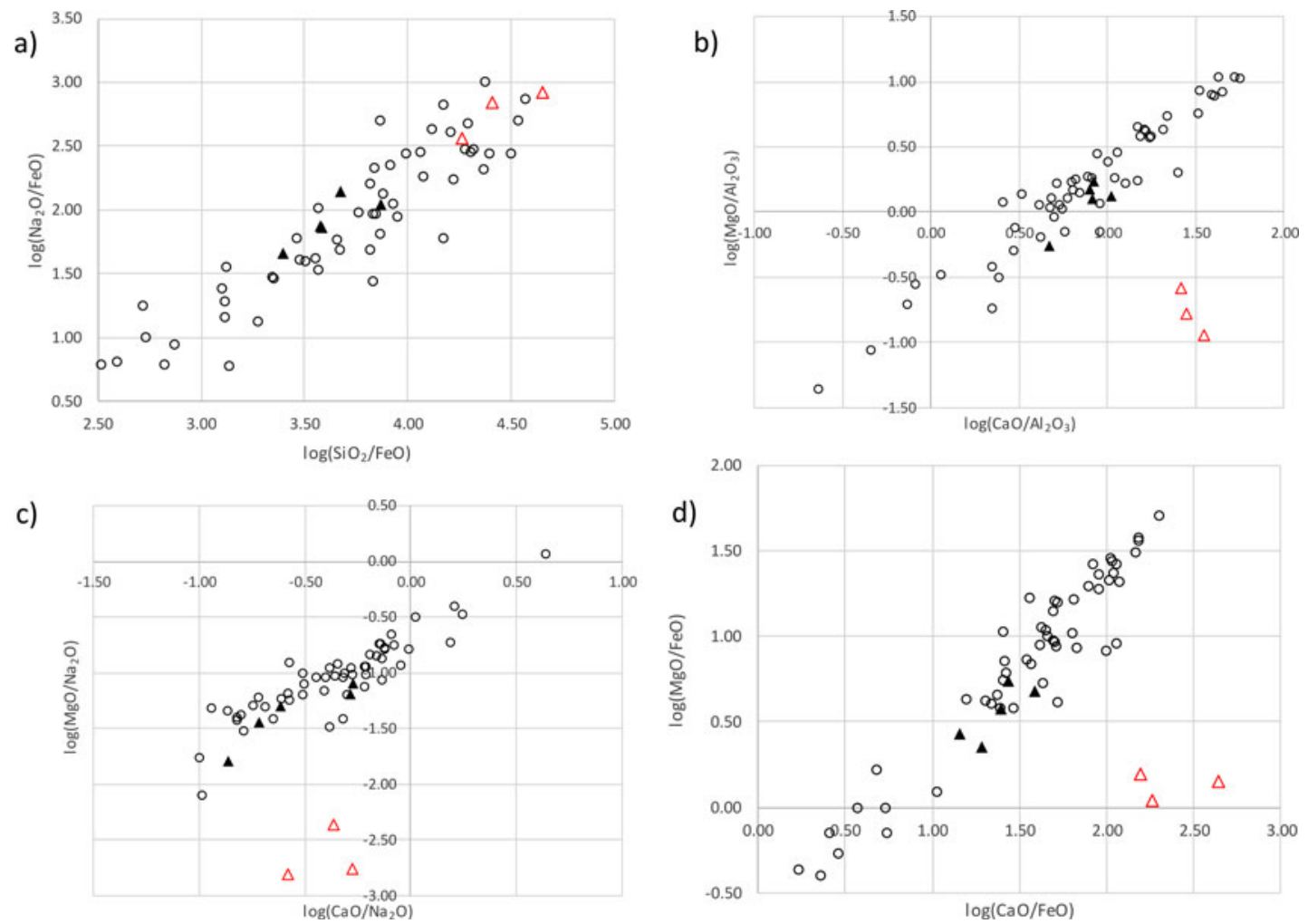

Fig. 4 Log-ratio plots of the glaze compositions for the legacy data and the Ain Sinu glazed sherds: a) log $\left(\mathrm{Na}_{2} \mathrm{O} / \mathrm{FeO}\right)$ vs $\log \left(\mathrm{SiO}_{2} / \mathrm{FeO}\right)$; b) $\log \left(\mathrm{MgO} / \mathrm{Al}_{2} \mathrm{O}_{3}\right)$ vs $\log \left(\mathrm{CaO} / \mathrm{Al}_{2} \mathrm{O}_{3}\right)$; c) $\log \left(\mathrm{MgO} / \mathrm{Na}_{2} \mathrm{O}\right)$ vs $\log \left(\mathrm{CaO} / \mathrm{Na} \mathrm{O}_{2} \mathrm{O}\right)$; and $\mathrm{d}) \log (\mathrm{MgO} / \mathrm{FeO})$ vs $\log (\mathrm{CaO} / \mathrm{FeO})$. Open circles are from the legacy data (Table 1$)$. Triangles show the samples from Ain Sinu (Table 4). Open (red in online version) triangles are those glazes from Ain Sinu which appear to have been fluxed using natron (highlighted in Table 4), i.e., Roman glass.

unexpected result for the main components of plant ash that would have been added together as part of the glaze recipe. This is discussed below. Furthermore, there is very little co-dependence between $\mathrm{FeO}$ and $\mathrm{Al}_{2} \mathrm{O}_{3}$ (0.386), or between either of these components and the other oxides in the table. This suggests variation in the silica source for the production of the glazes or during application of the glazes.

Common links derived from the variation matrix suggest that a projection of selected variables onto a particular direction is quasi-constant for the following sub-compositions: a) $\mathrm{Na}_{2} \mathrm{O}-\mathrm{SiO}_{2}-$ $\mathrm{FeO}$; b) $\mathrm{Al}_{2} \mathrm{O}_{3}-\mathrm{MgO}-\mathrm{CaO}$; c) $\mathrm{Na}_{2} \mathrm{O}-\mathrm{MgO}-\mathrm{CaO}$ and d) $\mathrm{FeO}-\mathrm{MgO}-\mathrm{CaO}$. These sub-compositions were used to determine compositional signatures for Parthian and Sasanian glazes and produced legacy data bands on log-ratio plots (Fig. 4a-d).

\section{Experimental methods and materials}

Sample selection was carried out at the Department of the Middle East: Ancient Iran and Arabia of the British Museum (BM) for Parthian glazed wares. It should be noted that although the BM collection has ceramic sherds and artefacts from the Parthian and Sasanian periods (Fig. 3), it has very few glazed ceramics, with an estimate of around $15 \%$ of the total collection. Eight glazed sherds were selected from Ain Sinu in Iraq (BM codes: 1988,0410.126, 156, 157, 163, 169-171, 176), which had been excavated at the Roman Legionary fort by Professor David Oates and Dr Joan Oates and were described as late Parthian (c. early third century A.D.) (Oates and Oates 1959).

The body fabrics of the eight Ain Sinu samples and 18 Mesopotamian pottery fabrics from Nineveh (2), Babneet (1), Siraf (6) and Uqair (9) held at the British Museum were measured 
TABLE 3 Compositional analyses of body fabrics for the major element oxides in the experimental study compared with literature values for Mesopotamian pottery (Simpson 1997b). Numbers of samples tested are in italics. Standard deviations are in parentheses below the mean compositional values. All samples analysed are presented in normalised compound percent ( $\mathrm{wt} \%$ oxide).

\begin{tabular}{lllllllll}
\hline & $\mathrm{SiO} 2$ & $\mathrm{TiO}_{2}$ & $\mathrm{Al}_{2} \mathrm{O}_{3}$ & $\mathrm{FeO}$ & $\mathrm{MgO}$ & $\mathrm{CaO}$ & $\mathrm{Na}_{2} \mathrm{O}$ & $\mathrm{K}_{2} \mathrm{O}$ \\
\hline $\begin{array}{l}\text { Typical Mesopotamian pottery (Simpson } \\
\text { 1997b) }\end{array}$ & 51 & 0.6 & 15 & 6 & 6 & 17 & 2 & 2 \\
Ain Sinu sherds (8) & 51.02 & $0.76^{*}$ & 12.26 & 6.57 & 5.00 & 20.01 & 1.53 & 1.55 \\
& $(3.15)$ & $(0.11)$ & $(0.60)$ & $(0.49)$ & $(0.64)$ & $(3.67)$ & $(0.57)$ & $(0.58)$ \\
Mesopotamian (18) & 50.49 & $0.69^{*}$ & 11.84 & 6.54 & 6.62 & 19.81 & 1.99 & 1.24 \\
& $(2.63)$ & $(0.03)$ & $(0.65)$ & $(0.50)$ & $(0.74)$ & $(3.25)$ & $(0.39)$ & $(0.35)$ \\
Ain Sinu 'natron' sherds (3) & 48.93 & $0.74 *$ & 11.92 & 6.76 & 4.96 & 22.81 & 1.08 & 1.26 \\
& $(2.58)$ & $(0.05)$ & $(0.63)$ & $(0.44)$ & $(0.92)$ & $(2.06)$ & $(0.30)$ & $(0.34)$
\end{tabular}

*ICP-MS was used for minor and trace levels of oxides. ICP-OES was used for all other oxides.

alongside standards JGb1 and NIM-G and a clay sample of known composition, using inductively coupled plasma optical emission spectroscopy (ICP-OES) and mass spectrometry (ICP-MS) (conducted on a Thermo X Series 2 Inductively-Coupled Plasma Mass Spectrometer at the School of Earth \& Ocean Sciences, Cardiff University).

Glazes were measured using a Hitachi S-3400N SEM with an attached energy dispersive x-ray spectrometer (EDS) (Oxford Instruments, UK) as this was the preferred technique used in much of the legacy data for analysing glaze compositions. Furthermore, it allowed representative glaze compositions to be measured, i.e. focussing on areas over $150 \mu \mathrm{m}$ from the interface of the body of the sherd and also away from weathered outer edges. A conductive carbon-coating was applied to the sample, which was examined at working distance of $10 \mathrm{~mm}$ using a voltage of $20 \mathrm{keV}$. An acquisition time of 100 seconds was used with a dead time between $35-40 \%$. The SEM-EDS was optimised using cobalt prior to any analytical work, and approximately every 90 minutes during scanning. Relative accuracy values determined from archaeological glass standards (Corning A and B) were better than $10 \%$ for all the major element oxides. Antimony concentrations were measured on the Ain Sinu glazes using a JEOL JXA-8100 electron probe microanalyser (EPMA) with a wavelength dispersive $\mathrm{X}$-ray spectrometer (WDS), run with a $20 \mathrm{kV}$ accelerating voltage and a probe current of $5 \times 10^{-8} \mathrm{nA}$. Samples were examined at a working distance of $11 \mathrm{~mm}$. The analyses were done at full screen scans at x800 magnification (equivalent of about $50 \times 80 \mu \mathrm{m}$ ). The accuracy of the calibration and the validity of the ZAF correction procedures were tested by repeat analyses of Corning $\mathrm{A}$ and $\mathrm{B}$ glass standards.

\section{Ain Sinu pottery fabric and glaze compositions}

No significant differences in the major, minor or trace element concentrations were found between these Mesopotamian fabrics and the fabrics from the Ain Sinu samples, with the major element oxides being consistent with average values for Mesopotamian body fabrics (Simpson 1997b) (Table 3). This strongly indicates that the Ain Sinu sherd fabrics are of Mesopotamian origin.

The Ain Sinu glaze compositions (Table 4) were plotted on the log-ratio plots with the legacy data (Fig. 4). The Ain Sinu glazes lie within the Parthian/Sasanian legacy data band in Fig. 4a, indicating that ratios involving $\mathrm{Na}_{2} \mathrm{O}, \mathrm{SiO}_{2}$ and $\mathrm{FeO}$ are relatively inflexible for glaze production irrespective of the find location, chronology or colour. Similarly, the majority of the Ain Sinu glazes fall within the Parthian/Sasanian legacy data bands for the other plots (Fig. 4b-d) suggesting that these glazed wares are from the same tradition as the legacy data. However, it is apparent that three sherds from Ain Sinu do not fall with the legacy data bands. The $\mathrm{MgO}$ concentrations for these glazes (MgO: $0.77 \mathrm{wt} \%$ for $1988,410.156 ; 0.86 \mathrm{wt} \%$ for $1988,410.163 ; 1.14 \mathrm{wt} \%$ for $1988,410.171$ ) are considerably lower than the remaining Ain Sinu samples $(\mathrm{MgO}$ : mean $=3.08 \mathrm{wt} \%$; $\mathrm{s}=0.56 ; \mathrm{n}=5)$ and those of the legacy data ( $\mathrm{MgO}:$ mean $=3.84 \mathrm{wt} \% ; \mathrm{s}=0.89 ; \mathrm{n}=53$ ). These low concentrations of $\mathrm{MgO}$ are not considered to be the result of post-depositional leaching, as the level of $\mathrm{Na}_{2} \mathrm{O}$ (which is more susceptible to post- 
TABLE 4 Normalised mean glaze compositions of oxides for the Parthian samples from Ain Sinu in wt $\%$ oxide (i.e., compound \%), apart from chlorine which is measured in wt $\%$, measured using SEM-EDS. All absolute totals for the glazes were over 90\%. Numbers of analyses per sample are in italics. All EDS measurements were made over $150 \mu \mathrm{m}$ from the ceramic body to avoid any interaction layers and also away from weathered edges. Standard deviations are in parentheses below the mean compositional values. BDL indicates that the element oxide was not detected. NA denotes that there are an insufficient number of values to determine the standard deviation. EPMA was used to measure $\mathrm{Sb}_{2} \mathrm{O}_{5}$ concentrations in the glazes. The samples highlighted in bold (red in online version) are the three samples which were found to lie outside the legacy data bands in Fig. 4 (a-d).

\begin{tabular}{|c|c|c|c|c|c|c|c|c|c|c|c|c|c|c|c|}
\hline 1988,410.\# & $\mathrm{Na}_{2} \mathrm{O}$ & $M g O$ & $\mathrm{Al}_{2} \mathrm{O}_{3}$ & $\mathrm{SiO}_{2}$ & $\mathrm{P}_{2} \mathrm{O}_{5}$ & $\mathrm{SO}_{3}$ & $\mathrm{Cl}$ & $\mathrm{K}_{2} \mathrm{O}$ & $\mathrm{CaO}$ & $\mathrm{TiO}_{2}$ & $\mathrm{MnO}$ & $\mathrm{FeO}$ & $\mathrm{CuO}$ & $\mathrm{PbO}$ & $\mathrm{Sb}_{2} \mathrm{O}_{5}$ \\
\hline $126(6)$ & $\begin{array}{c}11.52 \\
(0.61)\end{array}$ & $\begin{array}{c}3.51 \\
(0.26)\end{array}$ & $\begin{array}{c}3.11 \\
(0.39)\end{array}$ & $\begin{array}{l}63.84 \\
(0.69)\end{array}$ & $\begin{array}{c}0.48 \\
(0.07)\end{array}$ & $\begin{array}{c}0.55 \\
(0.09)\end{array}$ & $\begin{array}{c}0.22 \\
(0.10)\end{array}$ & $\begin{array}{c}4.28 \\
(0.06)\end{array}$ & $\begin{array}{c}8.65 \\
(0.56)\end{array}$ & $\begin{array}{r}0.23 \\
(0.03)\end{array}$ & $\begin{array}{l}\text { BDL } \\
\text { (NA) }\end{array}$ & $\begin{array}{c}1.77 \\
(0.13)\end{array}$ & $\begin{array}{c}2.05 \\
(0.13)\end{array}$ & $\begin{array}{c}0.50 \\
\text { (NA) }\end{array}$ & $\begin{array}{l}\text { BDL } \\
\text { (NA) }\end{array}$ \\
\hline 156 (5) & $\begin{array}{l}12.25 \\
(0.45)\end{array}$ & $\begin{array}{c}0.77 \\
(0.15)\end{array}$ & $\begin{array}{c}1.98 \\
(0.11)\end{array}$ & $\begin{array}{l}69.27 \\
(0.51)\end{array}$ & $\begin{array}{l}\text { BDL } \\
\text { (NA) }\end{array}$ & $\begin{array}{c}0.38 \\
(0.03)\end{array}$ & $\begin{array}{c}0.52 \\
(0.16)\end{array}$ & $\begin{array}{c}2.74 \\
(0.03)\end{array}$ & $\begin{array}{c}9.29 \\
(0.29)\end{array}$ & $\begin{array}{l}\text { BDL } \\
\text { (NA) }\end{array}$ & $\begin{array}{l}\text { BDL } \\
\text { (NA) }\end{array}$ & $\begin{array}{c}0.66 \\
(0.16)\end{array}$ & $\begin{array}{c}1.75 \\
(0.55)\end{array}$ & $\begin{array}{c}0.59 \\
(0.08)\end{array}$ & $\begin{array}{c}0.39 \\
(0.03)\end{array}$ \\
\hline 157 (9) & $\begin{array}{l}11.01 \\
(0.11)\end{array}$ & $\begin{array}{c}2.99 \\
(0.08)\end{array}$ & $\begin{array}{c}2.36 \\
(0.21)\end{array}$ & $\begin{array}{c}68.13 \\
(1.07)\end{array}$ & $\begin{array}{c}0.46 \\
(0.03)\end{array}$ & $\begin{array}{c}0.40 \\
(0.06)\end{array}$ & $\begin{array}{c}0.37 \\
(0.06)\end{array}$ & $\begin{array}{c}4.10 \\
(0.09)\end{array}$ & $\begin{array}{c}5.96 \\
(0.37)\end{array}$ & $\begin{array}{r}0.30 \\
(0.06)\end{array}$ & $\begin{array}{l}\text { BDL } \\
\text { (NA) }\end{array}$ & $\begin{array}{c}1.42 \\
(0.18)\end{array}$ & $\begin{array}{c}2.92 \\
(0.20)\end{array}$ & $\begin{array}{l}\text { BDL } \\
\text { (NA) }\end{array}$ & $\begin{array}{l}\text { BDL } \\
\text { (NA) }\end{array}$ \\
\hline $163(9)$ & $\begin{array}{l}14.24 \\
(0.77)\end{array}$ & $\begin{array}{c}0.86 \\
(0.16)\end{array}$ & $\begin{array}{c}1.87 \\
(0.05)\end{array}$ & $\begin{array}{l}68.12 \\
(0.39)\end{array}$ & $\begin{array}{l}\text { BDL } \\
\text { (NA) }\end{array}$ & $\begin{array}{c}0.41 \\
(0.04)\end{array}$ & $\begin{array}{c}0.75 \\
(0.02)\end{array}$ & $\begin{array}{c}1.80 \\
(0.30)\end{array}$ & $\begin{array}{c}7.96 \\
(0.18)\end{array}$ & $\begin{array}{r}0.23 \\
(0.02)\end{array}$ & $\begin{array}{c}0.22 \\
(0.02)\end{array}$ & $\begin{array}{c}0.83 \\
(0.18)\end{array}$ & $\begin{array}{c}3.03 \\
(0.24)\end{array}$ & $\begin{array}{l}\text { BDL } \\
\text { (NA) }\end{array}$ & $\begin{array}{c}0.47 \\
(0.04)\end{array}$ \\
\hline $171(6)$ & $\begin{array}{l}12.16 \\
(0.49)\end{array}$ & $\begin{array}{c}1.14 \\
(0.33)\end{array}$ & $\begin{array}{c}2.04 \\
(0.08)\end{array}$ & $\begin{array}{l}66.91 \\
(0.59)\end{array}$ & $\begin{array}{l}\text { BDL } \\
\text { (NA) }\end{array}$ & $\begin{array}{c}0.41 \\
(0.04)\end{array}$ & $\begin{array}{c}0.74 \\
(0.06)\end{array}$ & $\begin{array}{c}3.49 \\
(0.04)\end{array}$ & $\begin{array}{c}8.42 \\
(0.18)\end{array}$ & $\begin{array}{l}\text { BDL } \\
\text { (NA) }\end{array}$ & $\begin{array}{c}0.23 \\
(0.00)\end{array}$ & $\begin{array}{c}0.94 \\
(0.21)\end{array}$ & $\begin{array}{c}3.36 \\
(0.54)\end{array}$ & $\begin{array}{c}0.54 \\
(0.02)\end{array}$ & $\begin{array}{c}0.37 \\
(0.02)\end{array}$ \\
\hline $169(9)$ & $\begin{array}{l}11.88 \\
(0.28)\end{array}$ & $\begin{array}{c}2.81 \\
(0.29)\end{array}$ & $\begin{array}{c}2.35 \\
(0.48)\end{array}$ & $\begin{array}{c}64.98 \\
(1.30)\end{array}$ & $\begin{array}{c}0.45 \\
(0.05)\end{array}$ & $\begin{array}{c}0.35 \\
(0.02)\end{array}$ & $\begin{array}{c}0.39 \\
(0.02)\end{array}$ & $\begin{array}{c}3.41 \\
(0.09)\end{array}$ & $\begin{array}{c}5.80 \\
(0.25)\end{array}$ & $\begin{array}{r}0.36 \\
(0.12)\end{array}$ & $\begin{array}{l}\text { BDL } \\
\text { (NA) }\end{array}$ & $\begin{array}{c}1.82 \\
(0.45)\end{array}$ & $\begin{array}{c}4.60 \\
(0.41)\end{array}$ & $\begin{array}{c}1.09 \\
(0.14)\end{array}$ & $\begin{array}{l}\text { BDL } \\
\text { (NA) }\end{array}$ \\
\hline $170(7)$ & $\begin{array}{c}14.11 \\
(0.26)\end{array}$ & $\begin{array}{c}2.34 \\
(0.15)\end{array}$ & $\begin{array}{c}3.04 \\
(0.88)\end{array}$ & $\begin{array}{l}64.47 \\
(0.63)\end{array}$ & $\begin{array}{c}0.48 \\
(0.06)\end{array}$ & $\begin{array}{c}0.39 \\
(0.08)\end{array}$ & $\begin{array}{c}0.29 \\
(0.04)\end{array}$ & $\begin{array}{c}3.52 \\
(0.21)\end{array}$ & $\begin{array}{c}5.96 \\
(0.58)\end{array}$ & $\begin{array}{r}0.34 \\
(0.06)\end{array}$ & $\begin{array}{l}\text { BDL } \\
\text { (NA) }\end{array}$ & $\begin{array}{c}1.64 \\
(0.14)\end{array}$ & $\begin{array}{c}2.96 \\
(0.27)\end{array}$ & $\begin{array}{c}0.77 \\
(0.11)\end{array}$ & $\begin{array}{l}\text { BDL } \\
\text { (NA) }\end{array}$ \\
\hline $176(7)$ & $\begin{array}{c}11.14 \\
(0.77)\end{array}$ & $\begin{array}{c}3.75 \\
(0.53)\end{array}$ & $\begin{array}{c}3.38 \\
(0.39)\end{array}$ & $\begin{array}{l}62.80 \\
(0.33)\end{array}$ & $\begin{array}{c}0.95 \\
(0.16)\end{array}$ & $\begin{array}{c}0.45 \\
(0.08)\end{array}$ & $\begin{array}{c}0.34 \\
(0.09)\end{array}$ & $\begin{array}{c}4.00 \\
(0.24)\end{array}$ & $\begin{array}{c}8.49 \\
(0.90)\end{array}$ & $\begin{array}{r}0.30 \\
(0.05)\end{array}$ & $\begin{array}{l}\text { BDL } \\
\text { (NA) }\end{array}$ & $\begin{array}{c}2.10 \\
(0.11)\end{array}$ & $\begin{array}{c}2.31 \\
(0.27)\end{array}$ & $\begin{array}{l}\text { BDL } \\
\text { (NA) }\end{array}$ & $\begin{array}{l}\text { BDL } \\
\text { (NA) }\end{array}$ \\
\hline
\end{tabular}


TABle 5 Composition of typical Roman glass (Freestone 1991) with $\mathrm{Sb}_{2} 0_{5}$ values from Jackson and Paynter (2016) and the mean compositions of the three 'natron' samples $(1988,410.156 ; 1988,410.163$; and 1988,410.171) which fall outside the legacy data bands and the remaining five samples from Ain Sinu. $n$ denotes the number of sherds. BDL denotes levels below the detection limit. Note the similarity between the Ainu Sinu 'natron' glazes and the typical composition of Roman glass for these oxides, apart from $\mathrm{K}_{2} \mathrm{O}$.

\begin{tabular}{lcccccc}
\hline & $\mathrm{Na}_{2} \mathrm{O}$ & $\mathrm{MgO}$ & $\mathrm{SiO}_{2}$ & $\mathrm{~K}_{2} \mathrm{O}$ & $\mathrm{CaO}$ & $\mathrm{Sb}_{2} \mathrm{O}_{5}$ \\
\hline Typical Roman glass (Freestone 1991) & 16 & 0.5 & 68 & 0.5 & 8 & 0.54 \\
Ain Sinu 'natron' glazes (n=3) & 12.88 & 0.92 & 68.10 & 2.68 & 8.56 & 0.41 \\
Ain Sinu (n=5) & 11.93 & 3.08 & 64.84 & 3.86 & 6.97 & $\mathrm{BDL}$ \\
\hline
\end{tabular}

deposition loss) is not depleted in these three samples with respect to the other samples (Table 4). In fact, the low $\mathrm{MgO}$ concentrations for these three samples are more comparable with alkali glazes based on the evaporite natron, a form of hydrated sodium carbonate found as efflorescence around soda lakes (e.g., Wadi Natrun in Lower Egypt), rather than plant ash.

\section{Roman glass}

Table 5 shows that the typical composition of Roman glass, which was based on natron and is often classified as 'Low Magnesia' (Freestone 1991), is similar to the glaze compositions for the three Ain Sinu glazes with low magnesia levels. This would suggest that Roman glass was applied to Parthian fabrics to produce these glazes. Since Roman glaze production used lead-based glazes (Hatcher et al. 1994; Walton and Tite 2010), this would indicate that Roman natron glass was recycled to glaze Parthian pottery.

There are some differences between these three 'natron' glazes and Roman glass (Table 5). The $\mathrm{K}_{2} \mathrm{O}$ concentration is several times higher in these glazes $\left(\mathrm{K}_{2} \mathrm{O}: 2.74 \mathrm{wt} \%\right.$ for $1988,410.156 ; 1.80 \mathrm{wt}$ $\%$ for $1988,410.163 ; 3.49 \mathrm{wt} \%$ for $1988,410.171)$ than for Roman glass $\left(\mathrm{K}_{2} \mathrm{O}: 0.5 \mathrm{wt} \%\right)$. A possible explanation for these concentrations is evident from the low co-dependence between $\mathrm{K}_{2} \mathrm{O}$ and $\mathrm{MgO}$ (0.124 from the variation matrix) in the Parthian-Sasanian legacy data (Table 2), which had been anticipated to have higher co-dependence, as both potash and magnesia are components of the added plant ash. This could indicate that another source of potash entered the glaze systems, other than that associated with plant ash, i.e., a source unrelated to the initial composition of the glaze. Paynter (2009) suggests that differences between Mesopotamian glasses and glazes could be a consequence of contamination from fuel ash or vapour, especially hard-wood fuel. Since glazes have a higher surface area to volume ratio compared to glass heated in a crucible, ash or vaporised potassium compounds are more likely to affect the composition of a glaze by adhering to the molten surface. This would suggest that levels of $\mathrm{K}_{2} \mathrm{O}$ in the glazes investigated in this study (legacy and Ain Sinu glazes) could be a consequence of potassium compounds from the plant ash flux and the type of fuel used in Parthian and Sasanian kilns, thereby diminishing any co-dependence between $\mathrm{K}_{2} \mathrm{O}$ and $\mathrm{MgO}$ from the plant ash. This is supported by the invariance of $\mathrm{K}_{2} \mathrm{O}$ with increasing concentrations of $\mathrm{MgO}$ on a bivariate plot for the legacy data and the majority of the Ain Sinu glazes (Fig. 5). Moreover, the contamination argument outlined above could suggest that the three 'natron' samples (open triangles in Fig. 5) were produced in the same tradition as the other glazes, but that the starting composition of the glass was different to the other glazes tested here, and to those of the legacy data. It is therefore proposed that these three samples from Ain Sinu started out with lower concentrations of $\mathrm{K}_{2} \mathrm{O}$ (because they are Roman glass, fluxed using natron) but were contaminated with $\mathrm{K}_{2} \mathrm{O}$ because they were produced in the same tradition as the other glazes.

A further indication that these 'natron' glazes derive from Roman glass is evident from their antimony and manganese concentrations. Roman colourless glass from the first to third centuries A.D. was often decolourised using antimony (Jackson and Paynter 2016) (mean $=0.54 \mathrm{wt} \% \mathrm{Sb}_{2} \mathrm{O}_{5}$ - Table 5). The average results of the EPMA for $\mathrm{Sb}_{2} \mathrm{O}_{5}$ of the Ain Sinu samples are shown in Table 4 for the three 'natron' Ain Sinu glazes $\left(\mathrm{Sb}_{2} \mathrm{O}_{5}\right.$ : $0.39 \mathrm{wt} \%$ for $1988,410.156 ; 0.47 \mathrm{wt} \%$ for 


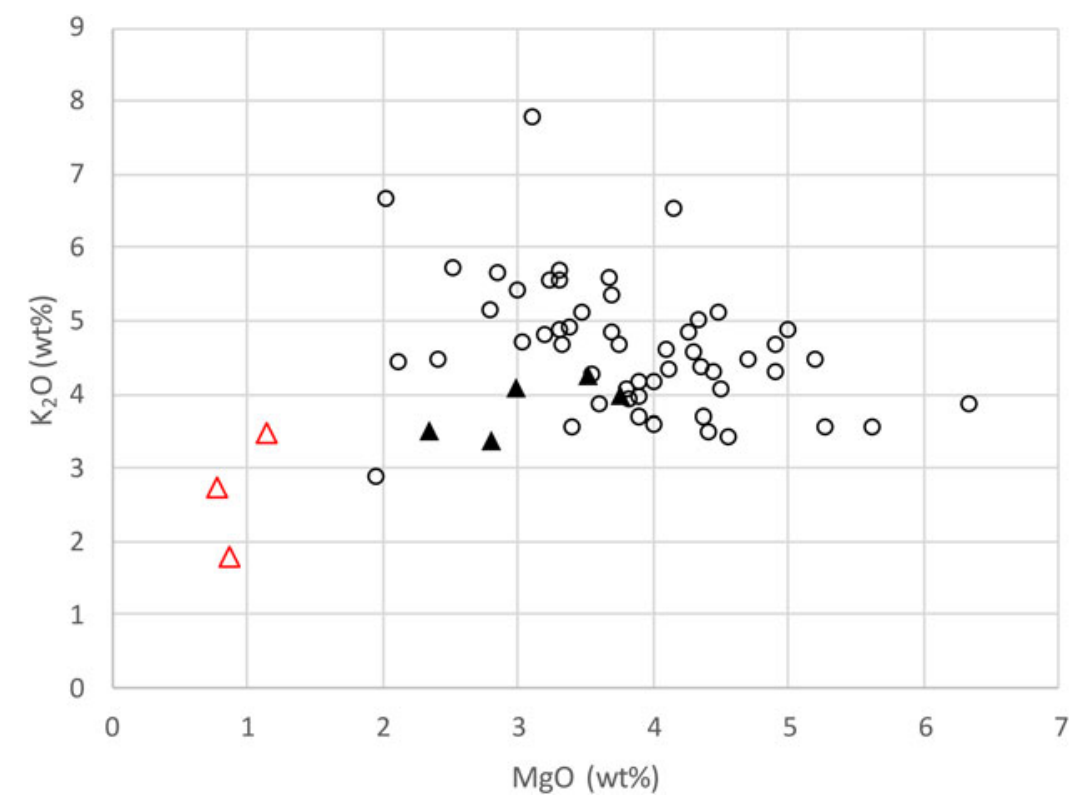

Fig. 5 A bivariate plot of $\mathrm{K}_{2} \mathrm{O}$ (potash) vs. $\mathrm{MgO}$ (magnesia). Open circles are from the legacy data (Table 1). Triangles show the samples from Ain Sinu (Table 4). Open (red in online version) triangles are those glazes from Ain Sinu which appear to have been fluxed using natron (highlighted in Table 4) which do not fall within the legacy data on the log-ratio plots (Fig. 4a-d), i.e., Roman glass.

$1988,410.163 ; 0.37 \mathrm{wt} \%$ for $1988,410.171)$. Furthermore, two of the three 'natron' glazes have significant $\mathrm{MnO}$ levels (MnO: $0.22 \mathrm{wt} \%$ for 1988,410.163; $0.23 \mathrm{wt} \%$ for 1988,410.171). All other sherds from Ain Sinu were below the detection limit for both antimony and manganese (Table 4). This could suggest that the Roman glass found on these two glaze samples had already been recycled, resulting in a mixture of decolourising agents, i.e., $\mathrm{Sb}_{2} \mathrm{O}_{5}$ and $\mathrm{MnO}$. In fact, at the extremes of the Roman world in the second and third centuries A.D., this recycled mixture appears to have become more readily available than the raw low-Mn blue-green glass (Jackson and Paynter 2016). The presence of mixed Roman glass, here reapplied as glaze on Parthian pottery, could reflect the potential difficulties experienced by this Roman outpost to acquire raw and 'pure' decolourised glass.

\section{Applying glass to glaze Parthian pottery}

The presence of Roman glass reapplied as a glaze on Parthian pottery suggests that the practice of glazing pottery in the Parthian Empire was to use a glass precursor in the form of a crushed glass frit, rather than applying a fluxing mineral to react directly with the silica-rich clay surface during firing. The low co-dependences of $\mathrm{FeO}$ and $\mathrm{Al}_{2} \mathrm{O}_{3}$ with the other oxides in the variation matrix (Table 2) could suggest that this frit was applied as a slurry of clay/mud, thereby introducing additional variability for these components above that associated with the production of the glass frit. For the three glazes which fail to lie within the legacy data bands in Fig. 4, this frit potentially derived from recycled Roman glass followed by typical Parthian methods of practice to fire a kiln and apply a glaze on a ceramic body. This practice indicates that glass and glaze were regarded as the same material in Mesopotamian production and that potters made their own frit specifically to glaze pottery and/or there are yet undiscovered glass production sites in Mesopotamia.

Extending recycling to indigenous glass production would provide an additional reason to weathering of glass as to the relatively low numbers of Parthian and Sasanian glass artefacts in the archaeological record, i.e., each glass vessel could have been recycled to glaze two or three pots of equivalent size. Furthermore, the fact that none of the Sasanian legacy glazes appears to be made 
from Roman glass could suggest that the Parthian glass/glaze industry was less developed than its Sasanian successors, with Parthian potters, in some instances, having to recycle imported material.

\section{Acknowledgements}

The authors would like to thank Dr Roberta Tomber, Dr St John Simpson and Dr Duncan Hook for access to the British Museum collection, and Professor Ian Freestone at the Institute of Archaeology, UCL.

\section{References Cited}

Aitchison, J. 1986. The statistical analysis of compositional data. London: Chapman and Hall.

2005. A concise guide to compositional data analysis. 2nd Compositional Data Analysis Workshop CoDaWork'05. Girona: Universitat de Girona. Available at: http://ima.udg.edu/Activitats/ CoDaWork05/A_concise_guide_to_compositional_data_analysis.pdf. (accessed 20 March 2019).

Brill, R. H. 2005. "Chemical analyses of some Sasanian glasses from Iraq: Appendix 2" in D. Whitehouse, ed. Sasanian and Post-Sasanian Glass in the Corning Museum of Glass. New York: Corning Museum of Glass.

Collinet, A. and R. Rante. 2013. Nishapur Revisited: Stratigraphy and Ceramics of the Qohandez. Oxford: Oxbow Books.

Freestone, I. C. 1991. "Looking into Glass" in S. Bowman, ed. Science and the Past. Toronto: University of Toronto Press, pp. 37-56.

2005. "The Provenance of Ancient Glass through Compositional Analysis". Materials Research Society Symposium Proceedings 852: 1-14.

2013. "Parthian, Sasanian and Early Islamic Pottery: Dating, definition and distribution" in S. Priestman and S.-J. Simpson, eds. A specialist workshop at The British Museum. Available at: http://www. britishmuseum.org/pdf/Pottery\%20seminar.pdf

Freestone, I. C. and Y. Gorin-Rosen. 1999. "The great glass slab at Beth She'arim: An early Islamic glass-making experiment?". Journal of Glass Studies 41: 105-116.

Hatcher, H., A. Kaczmarczyk, A. Scherer and R.P. Symonds. 1994. "Chemical Classification and Provenance of Some Roman Glazed Ceramics". American Journal of Archaeology 98: 431-456.

Hedges, R. E. M. and P. R. S. Moorey. 1975. "Pre-Islamic ceramic glazes at Kish and Nineveh in Iraq". Archaeometry 17: 25-43.

Hill, D. V. 2006. The Materials and Technology of Glazed Ceramics from the Deh Luran Plain, Southwestern Iran: A Study in Innovation. BAR International Series 1511. Oxford: BAR Publishing.

Jackson, C. M. and S. Paynter. 2016. "A great big melting pot: Exploring patterns of glass supply, consumption and recycling in Roman Coppergate, York". Archaeometry 58: 68-95.

Mason, R. B. 2004. Shine like the sun. Lustre-painted and associated pottery from the Medieval Middle East. Costa Mesa: Mazda Publishers.

Mason, R. B. and M.S. Tite. 1997. "The beginnings of tin-opacification of pottery glazes". Archaeometry 39:4158.

Matson, F. R. 1943. "Technological notes on the pottery" in N. Toll, ed. The excavations at Dura-Europus: Final Report IV - Pt. I Fascicle I - The green glazed pottery. New Haven: Yale University Press, pp. 81-95.

McCarthy, B. E. 1996. Microstructural and compositional studies of the technology and durability of ceramic glazes from Nippur, Iraq, ca. 250BC - 1450 AD. PhD Thesis, John Hopkins University.

Oates, D. 1968. Studies in the Ancient History of Northern Iraq. London: Oxford University Press for the British Academy.

Oates, D. and J. Oates. 1959. "Ain Sinu: A Roman frontier post in Northern Iraq". Iraq 21: 207-242.

Pace, M., A. Bianco Pervot, P. Mirti and R. Venco Ricciardi. 2008. "The technology of production of Sasanian glazed pottery from Veh Ardasir (Central Iraq)". Archaeometry 50: 591-605.

Paynter, S. 2009. "Links between glazes and glass in mid-2nd millennium BC Mesopotamia and Egypt" in A. J. Shortland, I.C. Freestone and T. Rehren, eds. From Mine to Microscope: Advances in the Study of Ancient Technology. Oxford: Oxbow Books, pp. 93-108.

Pawlowsky-Glahn, V. 2004. "Lecture Notes on Compositional Data Analysis". Girona: Universitat de Girona. http://www.compositionaldata.com/material_de_difusio/Kurs.pdf

Phelps, M., I. C. Freestone, Y. Gorin-Rosen and B. Gratuze. 2016. "Natron glass production and supply in the late antique and early medieval Near East: The effect of the Byzantine-Islamic transition". Journal of Archaeological Science 75: 57-71. 
Simpson, S-J. 1997a. "Partho-Sasanian Ceramic Industries in Mesopotamia" in I. C. Freestone and D. Gaimster eds. Pottery in the Making: World Ceramic Traditions. London: British Museum Press, pp. 74-79.

1997b. "Early Urban Ceramic Industries in Mesopotamia" in I. C. Freestone and D. Gaimster eds. Pottery in the Making: World Ceramic Traditions. London: British Museum Press, pp. 50-55.

van den Boogaart, K.G. 2013. Package 'compositions'. Available at: http://cran.r-project.org/web/packages/ compositions/compositions.pdf.

Walton, M. S. and M. S. Tite. 2010. "Production technology of Roman lead-glazed pottery and its continuance into Late Antiquity". Archaeometry 52: 733-759.

Wood, J. R. and Y-T. Hsu. 2019. "An archaeometallurgical explanation for the disappearance of Egyptian and Near Eastern cobalt-blue glass at the end of the Late Bronze Age". Internet Archaeology 52 https://doi. org/10.11141/ia.52.3

Jonathan R. Wood

Institute of Archaeology

University College London

London, UK

uczljrw@ucl.ac.uk

Yi-Ting Hsu

Department of Archaeology

University of Cambridge

Cambridge, UK

yth24@cam.ac.uk

إعادة استخدام زجاج روماني لتزجيج الفخار البارثي جوناثان وود و يي تنج هسو روني

استخدم التزجيج بمواد قلوية أول الأمر على الفخار الطيني في وادي الر افدين حوالي عام 1500 قبل البل المبلاد تزامنا مع ظهور الأوعية الزجاجية

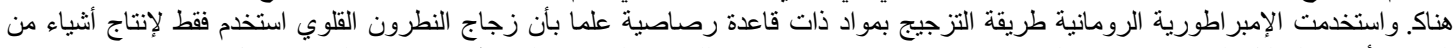

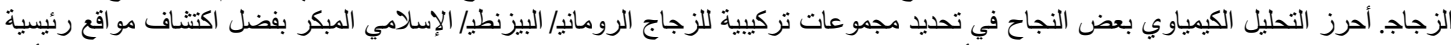

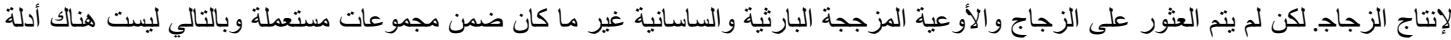

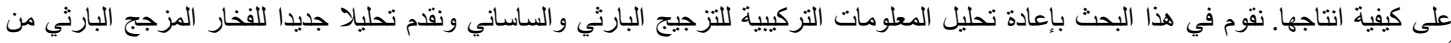

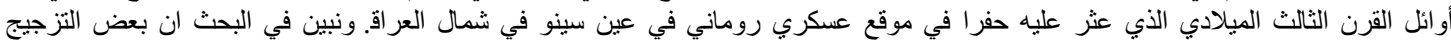

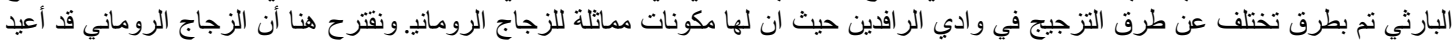

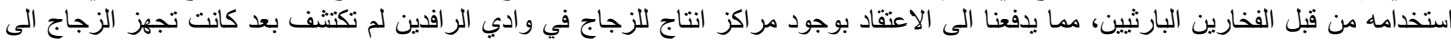

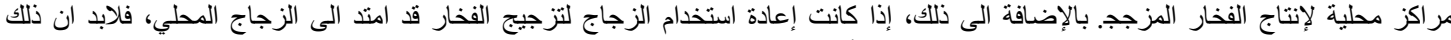
يفسر سبب ندرة الزجاج البارثي والساساني في السجلات الأثرية. 